\title{
Two Cases of Primary Papillary Thyroid Cancer with a Squamous Cell Carcinoma Component
}

\author{
Joon Seok Ko ${ }^{1}$, Jin Pyeong Kim ${ }^{1,2}$, Jung Je Park ${ }^{1,2}$ and Seung Hoon Woo ${ }^{1,2}$ \\ ${ }^{1}$ Department of Otorhinolaryngology Head and Neck Surgery, ${ }^{2}$ Institute of Health Sciences, School of Medicine, \\ Gyeongsang National University, Jinju, Korea
}

\section{갑상선에서 발생한 원발성 유두상-편평상피세포암 2예}

고준석 ${ }^{1} \cdot$ 김진평 ${ }^{1,2} \cdot$ 박정제 $^{1,2} \cdot$ 우승훈 ${ }^{1,2}$

경상대학교 의학전문대학원 이비인후과학교실, ${ }^{1}$ 건강과학연구원 ${ }^{2}$

\author{
Received July 24, 2012 \\ Revised October 31, 2012 \\ Accepted November 8, 2012 \\ Address for correspondence \\ Seung Hoon Woo, MD \\ Department of Otorhinolaryngology- \\ Head and Neck Surgery, \\ School of Medicine, \\ Gyeongsang National University, \\ 79 Gangnam-ro, \\ Jinju 660-702, Korea \\ Tel $+82-55-750-8173$ \\ Fax $+82-55-759-0613$ \\ E-mail lesaby@hanmail.net
}

Primary squamous cell carcinoma (SCC) of the thyroid is an unusual neoplasm. Recently, a new theory has been expounded suggesting that papillary thyroid carcinoma has an SCC component, as squamous differentiation is detected in only a portion of papillary thyroid carcinomas. We experienced two cases of primary squamous cell carcinoma of the thyroid. One case was an 82-year-old woman who underwent a total thyroidectomy. Histopathologic findings revealed that the squamous cell carcinoma was extended to the soft tissue. The woman was treated with postoperative radiotherapy, but her prognosis was poor. On the other hand, the case of a 31-year-old woman who was diagnosed with squamous cell carcinoma and papillary carcinoma within the thyroid displayed good prognosis. We review the literature and discuss these two cases that bring into focus the different prognoses.

Korean J Otorhinolaryngol-Head Neck Surg 2013;56:222-5

\section{서 론}

갑상선의 유두상암종은 전체 갑상선암의 약 $80 \%$ 를 차지 하는 흔한 암이나, 원발성 편평상피세포암은 전체 갑상선암 의 약 $1 \%$ 정도로 드물게 보고되고 있다.1,2)

정상적으로는 갑상선에 존재하지 않는 편평상피세포에서 유 래하는 편평상피세포암의 조직학적 기원에 관하여 여러 가지 가설이 존재하며, 최근에는 갑상선 여포세포가 편평상피화생 을 일으킨 후 악성 변화한 것으로 추정하고 있다. ${ }^{3)}$ 이러한 원발 성 편평상피세포암은 식도나 기도, 폐 등 타 부위에서 이차적 으로 갑상선으로 전이된 질환과 감별해야 하며, 최근 발표된 저널에서는 갑상선 유두상암종에 편평상피세포암이 부분적 으로 관찰되는 질환을 따로 구분하고 있다.,4) 호흡기나 소화기 계에서 이차적으로 갑상선으로 전이된 편평상피세포암은 외과 적 절제에 의해 완치될 수 있지만, 원발성 편평상피세포암은 어
떤 치료를 하더라도 예후가 불량하여 생존 기간이 진단 후 약 1 년 이하인 것으로 알려져 있다. 2,5,6)

저자들은 갑상선 내 유두상암과 편평상피세포암이 혼재하 는 2 증례를 경험하였고 주위 조직으로의 침범에 따라 각각의 환자의 예후가 저명하게 다르게 나타나 문헌 고찰과 함께 보 고하는 바이다.

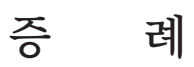

\section{증 례 1}

82세 여자 환자가 6개월 전부터 있었던 연하곤란을 주소로 내원하였다. 특별한 기저질환 없는 환자로 타병원에서 시행한 경부 초음파 상 갑상선 결절 소견이 관찰되어 본원으로 전원되 었다. 이학적 검사 결과 후두 내시경에서 좌측 성대마비 증상을 보였고, 좌측 전 경부에 $3 \mathrm{~cm}$ 크기의 경부 종물이 촉지되었다. 

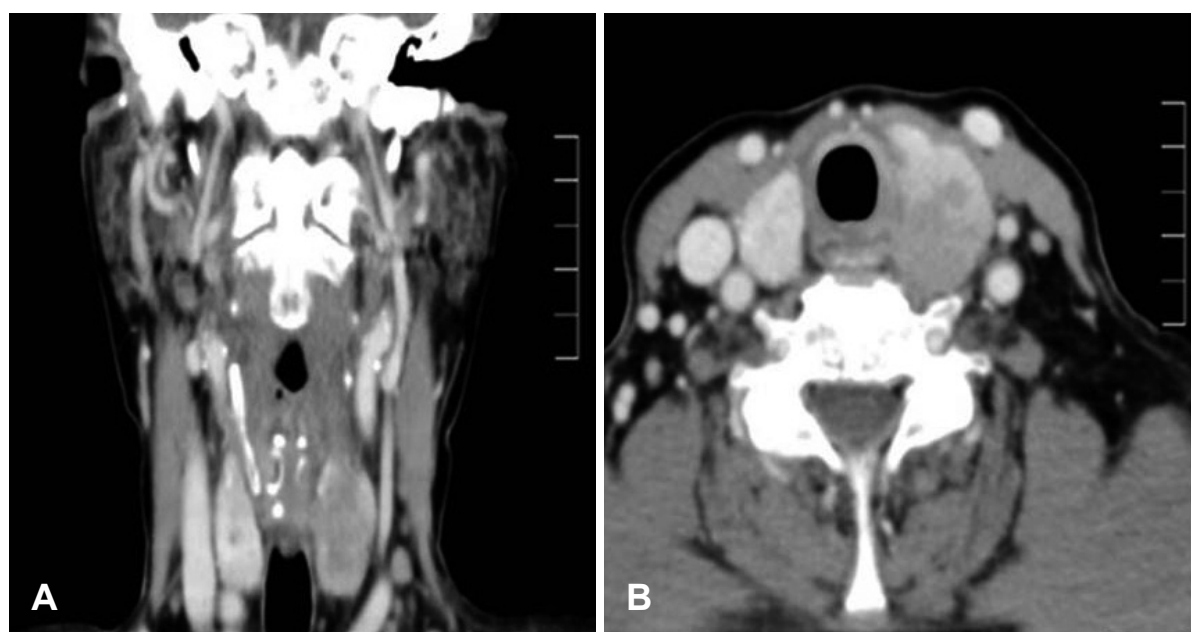

Fig. 1. The neck CT showed $3.2 \mathrm{~cm}$ sized non-specific nodule in the left thyroid lobe. This tumor extended to the around tissue (A: coronal view, $\mathrm{B}$ : axial view).

갑상선 결절 진단 하 경부 컴퓨터단층촬영과 초음파 유도 세 침흡인검사를 시행하였고, 경부 컴퓨터단층촬영에서는 갑상 선 좌엽에 약 $3.2 \mathrm{~cm}$ 크기의 종물 소견을 보였으며, 세침흡인 검사 결과 The Bethesda system $\mathrm{V}$ 로 갑상선 유두상암종이 의심되었고(Fig. 1), 갑상선 전 절제술과 양측 전경부 림프절 절 제술을 계획하였다. 수술장 소견 상 갑상선 주위 근육층의 침 범 소견을 보여 제거하였고, 좌측 되돌이 후두 신경도 침범소 견을 보여 제거하였다. 식도나 기도의 침범은 없었고 수술 후 특별한 합병증 없이 경과 관찰 하였다. 그러나 조직검사 결과 전이된 림프절은 보이지 않으나 갑상선 내부에 유두상암종과 편평상피세포암종이 혼재되어 있고 갑상선 주변 조직으로의 침범소견이 관찰되었다(Fig. 2). 술 후 편평상피암종의 원발부 위를 찾기 위해 위, 식도 내시경, 흥부 영상 검사, 복부 검사 그 리고 양전자방출단층촬영(PET-CT)을 시행하였으나 특이 소 견은 보이지 않았다. 따라서 갑상선에서 기원한 원발성 혼재성 갑상선 유두상암 및 편평상피세포암으로 진단되었다.

내분비내과, 방사선 종양학과와 협의하여 보조치료요법으 로 외부 방사선 조사 $5400 \mathrm{cGy}$ 를 6주에 걸쳐 시행하였다. 방 사선 치료 후 3 개월째 양전자방출단층촬영(PET-CT)을 시행 하였고, 양측 경부(좌측 level I, II, 우측 level IV)에 흡수(hotuptake) 소견이 관찰되었다. 광범위한 경부 절제술이 필요하였 으나 환자가 고령이고 수술에 대한 두려움이 심하여 보호자와 상의 후 최소한의 수술을 원하여 양측 선택적 경부 림프절 절 제술(selective neck dissection-좌측 level I, II, 우측 level III, IV)을 계획하고, 이전의 수술절개(incision)를 양측으로 확 장(extension)하여 수술을 시행하였다. 조직검사 결과 좌측 level II, 우측 level IV의 림프절에 갑상선에서 전이된 것으로 보 이는 편평상피세포암종 소견이 관찰되었다. 이후 외래 경과 관 찰 중 연하곤란 및 경부 통증을 호소하였으며, 추가 수술 3 개 월째 식도 입구부에 종물이 보여 국소적인 재발 의심 소견이 있

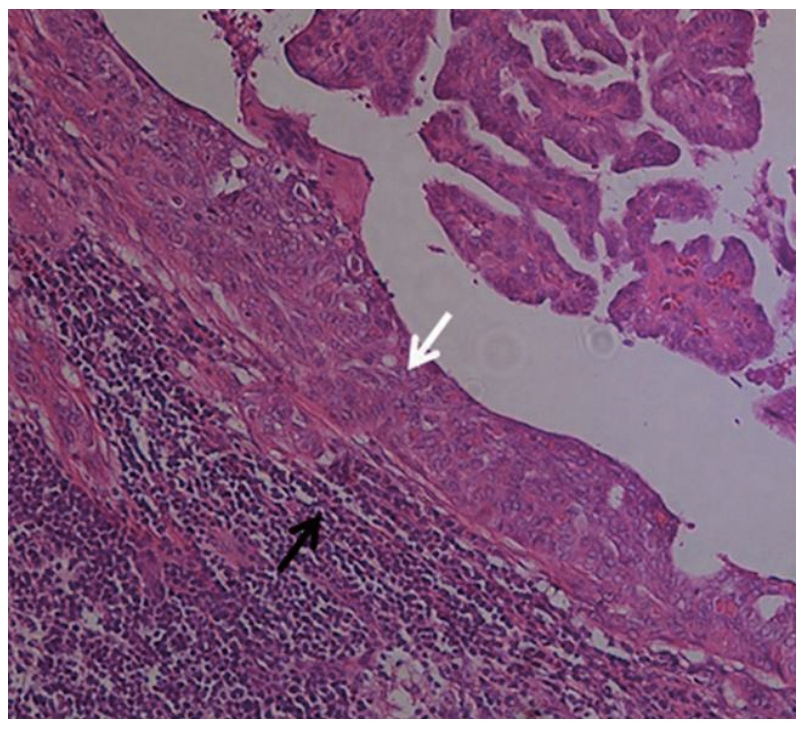

Fig. 2. This pathologic picture showed that the papillary thyroid cancer coexisted with squamous cell carcinoma. White arrow: papillary thyroid carcinoma. Black arrow: squamous cell carcinoma (H\&E; $\times$ 100).

었으나, 고령을 이유로 환자 및 보호자 추가적인 검사와 수술 을 거부하여 5 개월째 전신상태 악화로 사망하였다.

\section{증 례 2}

30세 여자 환자가 우연히 발견된 갑상선 결절을 주소로 내 원하였다. 갑상선 기능 검사는 정상이었고 초음파 검사상 결절 은 $1 \mathrm{~cm}$ 크기로 갑상선 우하엽에 위치하고 있었다. 결절은 내 부에 석회화 소견을 보이고 있었으며 주위 림프절의 종대 소견 은 없었다(Fig. 3). 갑상선 결절 진단 하에 초음파 유도 세침흡 인검사를 시행하였고 세침흡인검사 결과 The Bethesda system V로 갑상선 유두상암종이 의심되었다. 갑상선 유두상암 종 의증으로 갑상선 전 절제술과 양측 전경부 림프절 절제술 을 시행하였다. 수술 후 조직검사결과 유두상암과 편평상피세 

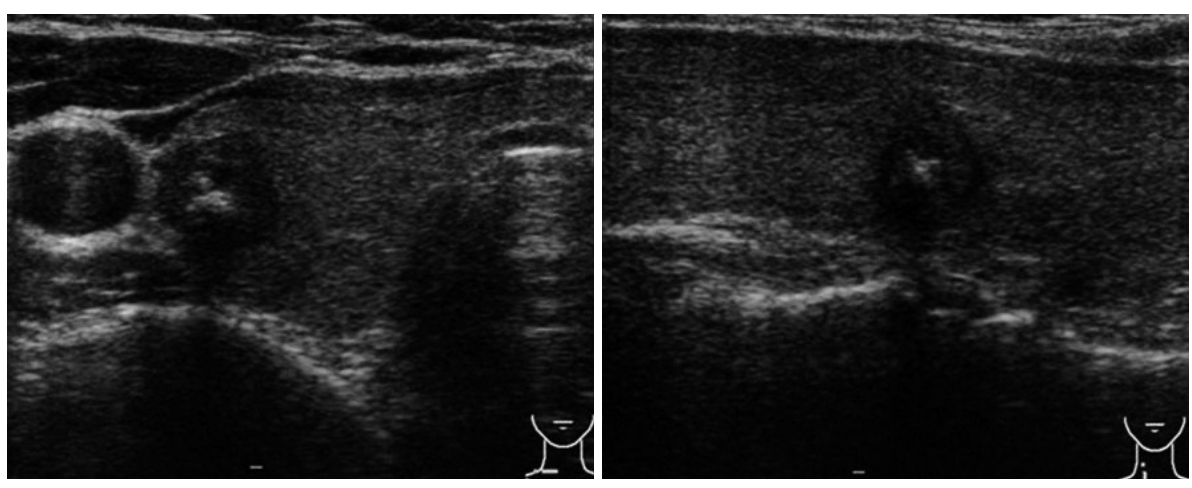

Fig. 3. The ultrasonography showed $1.0 \mathrm{~cm}$ sized nodule in the right thyroid lobe. This nodule had internal calcification and confirmed whitin a thyroid.
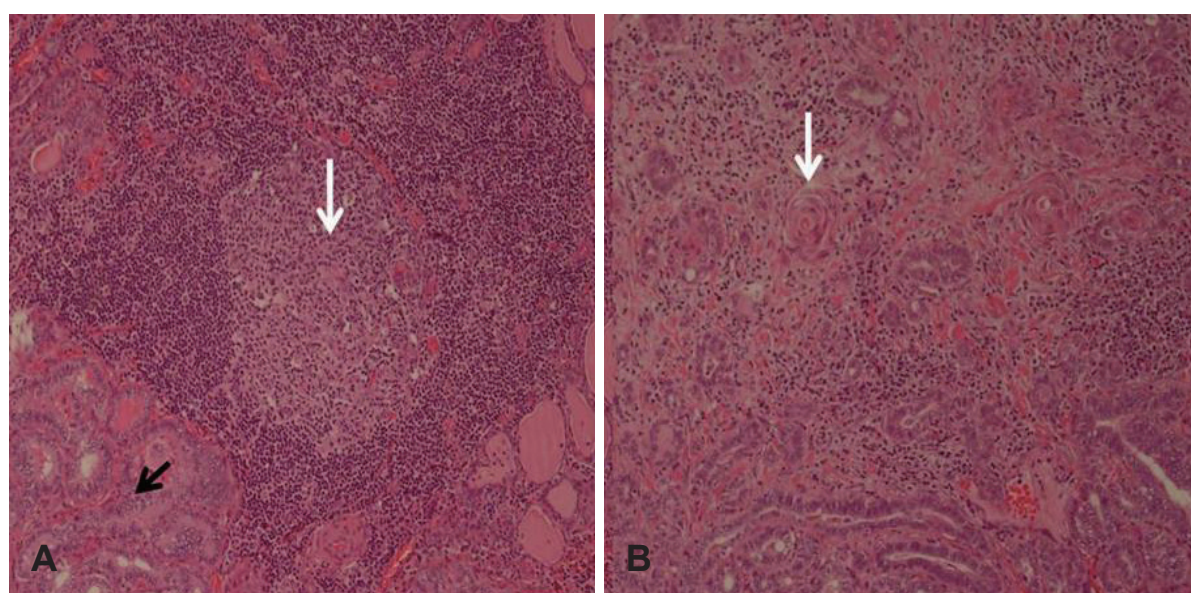

Fig. 4. This pathologic picture showed that the papillary thyroid cancer coexisted with squamous cell carcinoma. Central portion have squamous cell carcinoma (white arrow) and peripheral portion have papillary thyroid carcinoma (black arrow)(A). Keratin pearl (white arrow)(B). H\&E; ×100.

포암종이 혼재된 양상으로 크기는 $0.9 \times 0.8 \mathrm{~cm}$ 였으며 갑상선 에 국한되어 있었고, 국소 침범 및 림프절 전이 소견은 없었다 (Fig. 4). 외부에서 전이된 편평상피세포암종을 배제하기 위해 두경부 이학적 검사와 위, 식도 내시경 및 흥부 영상 검사, 복 부 검사 그리고 양전자방출단층촬영(PET-CT)을 시행하였으 나 원발부위를 의심할 만한 소견은 보이지 않았다. 따라서 원 발성 혼재성 갑상선 유두상암 및 편평상피세포암으로 진단하 였고, 2개월 후 방사선 요오드 치료 $(100 \mathrm{mCi})$ 를 시행하였으며 현재까지 갑상선 초음파 및 전신 스캔에서 재발소견 없이 12 개 월째 경과 관찰 중이다.

\section{고 찰}

갑상선에서 원발성으로 발생하는 편평상피세포암은 매우 드 물며, 발견되는 경우 대부분 유두상암종과 혼재하는 경우로 많이 발견되고 있다. ${ }^{1,2,4,7)}$ 과거에 보고된 여러 증례처럼 갑상 선의 유두상암종에 부분적으로 편평상피세포암이 관찰되는 부분이 있는 경우 "papillary thyroid carcinoma having a SCC component'로 표현하여 왔다. ${ }^{4)} \mathrm{WHO}$ 분류에서는 갑상선 내 발생한 원발성 편평상피세포암을 'squamous cell carcinoma of the thyroid'로 정의하고 있다. ${ }^{4)}$
갑상선에서 발생하는 편평상피세포암의 기원은 다양한 가 설이 있는데, 첫째, 유두상암을 포함한 여포세포에서 기원하는 종양의 편평상피화생에 의해 발생한다는 것, 둘째로는 갑상설 관, 흥선, 최종기관지체 등의 발생학적 잔유물에서 기원한 편평 상피세포에서 발생한다는 것, 셋째, 유두상암의 분화에 의해 발생한다는 것 등이 있다. ${ }^{3,-12)}$

갑상선의 편평상피세포암은 술 전에 시행하는 세침흡인세 포검사나 초음파검사, 갑상선 기능검사와 전산화단층촬영 등 이 정확한 진단에 크게 도움이 되지 않으며, 수술을 통한 최종 조직검사로 확진하는 경우가 대부분이다. ${ }^{1,24)}$ 특히 수술 전 시 행한 세포 검사에서는 염증세포 혹은 분화가 나쁜 악성세포, 부적절한 검체 등으로 술 전 세포 검사로 진단하기 어려운 경 우가 많으며, 수술 후 원발성 갑상선 편평상피세포암으로 확진 하기 위해서는 폐, 두경부, 식도, 상기도 등의 주변장기에서 전 이된 것이 아니어야 한다.

본 증례에서도 술 전 세침흡인세포검사에서 조직형을 구별 하기 어려운 여포세포와 핵 이형성이 보여 유두상암이 의심은 되었으나 편평상피세포암을 의심할 소견은 발견하지 못하였 고, 결국 수술을 통한 조직검사로 진단하였다. 술 후 이차성 편 평상피세포암을 배제하기 위해 위, 식도 내시경 및 흥부 및 복 부 영상 검사와 양전자방출단층촬영(PET-CT) 등의 전신 전 
이 검사를 시행하였다.

원발성 갑상선 편평상피세포암도 다른 편평상피세포암의 전형적인 특성과 마찬가지로 갑작스러운 종괴의 크기를 경험 하는 경우가 많으며, 40 60대에서 갑상선염이나 갑상선종의 긴 병력을 가지고 있었던 환자에서 발생하며, 보고된 몇몇 증 례에서와 같이 수술 당시 대부분 주위 근육이나 기도, 식도 등 에 침범되어 있다. ${ }^{1,2,6,13,14)}$ 또, 급속히 진행하는 암으로 국소 침 범이나 전이를 하는 경향이 있으며, 다른 부가적인 치료에 반 응이 없어 임상적인 경과가 좋지 않다., ${ }^{1,2}$

이렇듯 예후가 좋지 않아 조기에 발견하여 완전 절제를 시 행하는 것이 필수적이며, 수술 전후 항암 화학 요법이나 방사 선 치료를 시도해 볼 수 있다.,2,4,6,13,14) 과거에는 방사선 요법 및 5-fluorouracil, bleomycin, vincristine 등의 화학 요법을 시도 하였으나 거의 효과가 없는 것으로 결론된 보고가 많았다.,13,14) 그러나 최근 발표된 저널에서는 술 전 화학 요법 및 전신 전이를 치료하기 위해 시행한 화학 요법에서 효과가 있다는 것과, 주 변 조직으로의 침범이 있는 경우 외부 방사선 조사가 효과가 있 다는 보고가 있다. ${ }^{4}$

예전에 발표된 여러 증례처럼 갑상선에 유두상암과 편평상 피세포암이 공존하고 있는 경우에는 특히 주위 조직으로 파 급되어 있는 경우가 많고, 빠르게 진행하며 국소 전이나 전신 전이와 재발률이 높아 대부분 1 년 내에 사망하는 것으로 보고 되고 있다. ${ }^{1,2,6,15)}$ 본 증례 1 의 경우에도 국소 및 전신 전이로 인 해 수술 후 방사선 치료를 시행하였음에도 결과가 좋지 않았 다. 그러나 증례 2와 같이 유두상암과 공존한 편평상피세포암 이 갑상선 실질 내에 위치하고 있어 갑상선 피막 및 주변 조직 으로의 침범이 없다면 갑상선 전 절제술과 전경부 림프절 절제 술, 술 후 방사선 요오드 치료만으로도 만족할 만한 경과를 얻 는 것을 경험할 수 있었다.

갑상선내 유두상암과 편평상피세포암이 동반된 경우가 매 우 드물기 때문에 이러한 증례들을 모아 예후를 분석하기는 쉽 지 않다. 저자들은 효과적인 치료방법이 아직 확립되지 않은 갑상선의 원발성 편평상피세포암과 혼재되어 있는 원발성 유 두상암에서, 갑상선 주위 조직으로 파급이 되어 수술 후에도
국소 재발 및 전이를 하여 예후가 불량한 증례와, 갑상선 실질 내에 국한되어 주위 조직으로 파급이 없는 경우 수술 및 술 후 방사선 요오드 치료로 예후가 양호하였던 증례를 경험하였기 에 문헌고찰과 함께 보고하는 바이다.

\section{REFERENCES}

1) Booya F, Sebo TJ, Kasperbauer JL, Fatourechi V. Primary squamous cell carcinoma of the thyroid: report of ten cases. Thyroid 2006;16(1): 89-93.

2) Müssig K, Dahm J, Koitschev A, Horger M, Müller M, Bares R, et al. Primary squamous cell carcinoma of the thyroid. Intern Med J 2008; 38(1):69-70

3) Korovin GS, Kuriloff DB, Cho HT, Sobol SM. Squamous cell carcinoma of the thyroid: a diagnostic dilemma. Ann Otol Rhinol Laryngol 1989;98(1 Pt 1):59-65.

4) Ito $Y$, Hirokawa $M$, Higashiyama $T$, Kihara $M$, Tomoda $C$, Takamura $\mathrm{Y}$, et al. Biological behavior of papillary carcinoma of the thyroid including squamous cell carcinoma components and prognosis of patients who underwent locally curative surgery. J Thyroid Res 2012;2012:230283.

5) Djalilian M, Beahrs OH, Devine KD, Weiland LH, DeSanto LW. Intraluminal involvement of the larynx and trachea by thyroid cancer. Am J Surg 1974;128(4):500-4.

6) Goldman RL. Primary squamous cell carcinoma of the thyroid gland: report of a case and review of the literature. Am Surg 1964;30:24752.

7) LiVolsi VA, Merino MJ. Squamous cells in the human thyroid gland. Am J Surg Pathol 1978;2(2):133-40.

8) Akbari Y, Richter RM, Papadakis LE. Thyroid carcinoma arising in thyroglossal duct remnants. Report of a case and review of the literature. Arch Surg 1967;94(2):235-9.

9) Burman KD, Ringel MD, Wartofsky L. Unusual types of thyroid neoplasms. Endocrinol Metab Clin North Am 1996;25(1):49-68.

10) Harada $T$, Shimaoka $K$, Yakumaru $K$, Ito $K$. Squamous cell carcinoma of the thyroid gland -- transition from adenocarcinoma. J Surg Oncol 1982;19(1):36-43.

11) Mobini J, Krouse TB, Klinghoffer JF. Squamous cell carcinoma arising in a thyroglossal duct cyst. Am Surg 1974;40(5):290-4.

12) Saito K, Kuratomi Y, Yamamoto K, Saito T, Kuzuya T, Yoshida S, et al. Primary squamous cell carcinoma of the thyroid associated with marked leukocytosis and hypercalcemia. Cancer 1981;48(9):2080-3.

13) Huang TY, Assor D. Primary squamous cell carcinoma of the thyroid gland: a report of four cases. Am J Clin Pathol 1971;55(1):93-8.

14) Prakash A, Kukreti SC, Sharma MP. Primary squamous cell carcinoma of the thyroid gland. Int Surg 1968;50(6):538-41.

15) Shimaoka K, Tsukada Y. Squamous cell carcinomas and adenosquamous carcinomas originating from the thyroid gland. Cancer 1980;46(8):183342. 